\title{
Trace Metals, Potassium Bromate and Nutritional Potentials in Bread from Bakeries in Uyo, Akwa Ibom State, Nigeria
}

\author{
Emmanuel Isaac Uwah", Ernest Daniel Ikwebe \\ Department of Chemistry, Faculty of Science, University of Uyo, Uyo, Nigeria \\ Email address: \\ emmanueliuwah@uniuyo.edu.ng (E. I. Uwah),ernest.ed90@gmail.com (E. D. Ikwebe) \\ ${ }^{*}$ Corresponding author
}

\section{To cite this article:}

Emmanuel Isaac Uwah, Ernest Daniel Ikwebe. Trace Metals, Potassium Bromate and Nutritional Potentials in Bread from Bakeries in Uyo, Akwa Ibom State, Nigeria. American Journal of Applied Chemistry. Vol. 8, No. 3, 2020, pp. 63-73. doi: 10.11648/j.ajac.20200803.11

Received: November 7, 2019; Accepted: November 25, 2019; Published: July 4, 2020

\begin{abstract}
This research assessed bread from bakeries in Uyo, Akwa Ibom State, Nigeria, for trace metals, nutritive value and potassium bromate using standard procedures. Samples were collected from four bakeries coded as: A, B, C and D. Alkaloids, glycosides, steroids and saponins were present in all samples. Flavonoids were only present in samples obtained from bakery D. Quantitatively, phytochemical composition ranged from $0.08 \pm 0.00 \mathrm{mg} / 100 \mathrm{~g}$ glycoside in samples from bakery A to $3.76 \pm 0.00 \mathrm{mg} / 100 \mathrm{~g}$ alkaloids also in samples from bakery A. Trace metal analysis indicated that copper was only detected in samples from bakery B, and that iron levels were less than $0.009 \mathrm{mg} / 100 \mathrm{~g}$ in all the samples, while tin was $<0.001 \mathrm{mg} / 100 \mathrm{~g}$ in samples from bakery A and was not detected in samples from bakeries B, C and D. The levels of potassium bromate analysed by the congo red oxidation method in all the samples ranged from $6.66 \pm 0.00$ to $52.19 \pm 0.00 \mathrm{mg} / \mathrm{kg}$. With crystal violet oxidation method, they ranged from $5.09 \pm 0.00$ to $58.36 \pm 0.01 \mathrm{mg} / \mathrm{kg}$. Proximate composition ranged from $0.03 \pm 0.00$ fiber in samples from $\mathrm{A}, \mathrm{C}$ and $\mathrm{D}$ to $73.38 \pm 0.00 \% \mathrm{CHO}$ in samples from $\mathrm{C}$, while the calorific values ranged from $280.11 \pm 0.00$ to $359 \pm 0.00 \mathrm{kcal}$ in all the samples. Anti-nutrient composition ranged from $0.21 \pm 0.00 \mathrm{mg} / 100 \mathrm{~g}$ tannin in samples from $\mathrm{B}$ to $1.68 \pm 0.00 \mathrm{mg} / 100 \mathrm{~g} \mathrm{HCN}$ in samples from C. Essential mineral composition ranged from $0.01 \pm 0.00 \mathrm{mg} / 100 \mathrm{~g}$ phosphorus and sodium in samples from A and D to $1.89 \pm 0.00 \mathrm{mg} / 100 \mathrm{~g}$ calcium in samples from B. Vitamins composition ranged from $0.19 \pm 0.00 \mathrm{mg} / 100 \mathrm{~g}$ vitamin $\mathrm{B} 2$ in samples from $\mathrm{D}$ to $4.62 \pm 0.00 \mathrm{mg} / 100 \mathrm{~g}$ vitamin $\mathrm{C}$ in samples from $\mathrm{C}$. The bread samples were to some extend nutritive. The anti-nutrients and trace metals in the bread were below the levels that could cause toxicity in humans, except that the bread contained potassium bromate (banned chemicals that are hazardous to human health).
\end{abstract}

Keywords: Bread, Bakeries, Uyo, Trace Metals, Nutritive Value, Potassium Bromate, Standard Procedures

\section{Introduction}

Nutrients are chemical substances in food that nourish the body by providing energy, building materials and factors to regulate needed chemical reactions in the body. Antinutrients are therefore, chemical substances in food that do not offer nourishment. Most anti-nutrients in food are however not poisonous in the concentration in which they are present. They are natural or synthetic compounds that interfere with the absorption of nutrients [1]. Examples include: phytic acid, oxalic acid, tannins and hydrocyanic acid.

Bread is widely consumed by people of all class, region, religion and sex. Bread is an important staple food of many countries of the world, especially the African countries and south east part of Asia [2,3]. It is cheap and easily prepared in almost all communities. It is consumed extensively in homes, restaurants and hotels [4]. It is a carbohydrate source made from flour and yeast with the flour fortified with potassium bromate for aesthetic purposes and which acts as flour improver that serves as a maturing agent for the purpose of preventing the dough from falling [5]. In addition, bread contains several ingredients such as salt, sugar, flavours, that help improve its quality [6]. Statistic had showed that in Nigeria, bread is one of the most consumed foods with predominant consumption among the poor [7].

Potassium bromate is widely used by bakers in bread making because of its slow oxidizing nature, availability in the market and low cost. Potassium bromate is used in the milling industry as a flour improver that acts as a maturing 
agent and in the baking industry for dough conditioning [5]. It use results in the production of high value and fine crumb. It acts as an oxidizing agent throughout the bread making processes: fermentation, proofing and baking, affecting the rheological properties of the final product [6]. Potassium bromate is used by many bakeries as an additive in the raising process and to produce a texture in the finished product that will attract the buyer [6].

Bromates are formed in many different ways. The most common is the reaction of ozone and bromide as given in (1).

$$
\mathrm{Br}-+\mathrm{O}_{3} \rightarrow \mathrm{BrO}_{3}^{-}
$$

Potassium bromate is reduced to potassium bromide during baking process in the oven and this is found to be innocuous in the finished product [6] (Ahmad, 2013). This is given in (2).

$$
2 \mathrm{KBrO}_{3} \rightarrow 2 \mathrm{KBr}+3 \mathrm{O}_{2}
$$

It is assumed that all the added bromate is reduced to bromide as in the above reaction (2). However, the reduction of the added bromate to bromide is dependent on the oven temperature, the duration of exposure at that temperature and the quantity of potassium bromate used. According to [6], it is conceivable that some bromate residue may be left in the finished baked product. Studies have shown that potassium bromate have some side effects that ranged from mild to toxic. Studies have also shown that if adequate heat is not applied during the baking process, some of the bromate might not be completely reduced to bromide, thereby, making the use of potassium bromate by bakers hazardous to consumers [6].

Scientific evidence has implicated potassium bromate as a possible carcinogen and it has been removed from the list of acceptable additives for flour treatment [6]. Accordingly, the National Agency for Food and Drug Administration and Control (NAFDAC) had in 2002 announced the dangers associated with the use of potassium bromate and banned its further use in bread. Some bakeries however, are still making use of potassium bromate as dough improver, since it is known to be one of the best dough improvers in the bakery industries. Indeed, the use of potassium bromate is a common choice among flour millers and bakers throughout the world, because it is cheap and probably the most efficient oxidizing agent. According to [5], potassium bromate acts as a slow oxidizing agent throughout the fermentation, proofing and baking processes, affecting the structure and rheological properties of the dough. As a result, many bakeries use potassium bromate as an additive to assist in the raising process and to produce a texture in the finished product that is appealing to the public.

Trace metals are potential environmental contaminants capable of finding their ways into the foods we eat and causing human health problems [4]. Several cases of human disease, disorder, malfunction and malformation of organs due to metal toxicity have been reported. The major route for human exposure to trace metal is the food pathway [4].
Trace metals are among the most insidious contaminants due to their non-biodegradable nature and their ability to cause adverse effects at certain levels of exposure and absorption [8]. The harmful effects of trace metals are linked to their accumulation in biological system even in their lowest form of development. It has been reported that processing of cereals such as milling, baking and bread baking processes have considerable effects on the levels of some trace metals in the final products [9]. Food processing equipment and containers have long been recognised as sources of trace metals in the food industries [10]. Flour produced from contaminated raw materials, the water used for bread baking and the kind of baking fuel used for bread production could be responsible for trace metal contamination of bread [4]. Despite being a major staple food in many homes, there is little information on the levels of trace metals in bread produced in different parts of the world [4]. Hence, there is every need for this study.

The reason for this research, therefore, is to ascertain the suitability of bread from bakeries in Uyo, Akwa Ibom State, Nigeria, for human consumption by establishing the levels of some trace metals (iron, lead, copper and tin), phytochemical composition (alkaloids, flavonoids, saponins, steroids and glycosides), levels of some essential minerals (calcium, sodium and phosphorus) and the vitamin contents (vitamin A, vitamin $\mathrm{C}$ and riboflavin) as well as anti-nutrient contents (tannins, oxalate, cyanide and assessing the level of compliance by the bakeries with the ban on the use of potassium bromate in bread by NAFDAC. Data generated from this study will serve as baseline reference for other researchers in the area.

\section{Materials and Methods}

\subsection{Samples Collection and Preparation}

Freshly baked bread samples were collected in clean containers from four (4) different bakeries (coded A, B, C and D) in Uyo, Akwa Ibom State. Samples were properly labeled and transported to the laboratory for preparation and analyses. All chemicals and reagents used were of analytical standard.

\subsection{Phytochemical Analysis (Qualitative)}

The following qualitative tests for phytochemical analysis were carried out on the extracts of oven dried powdered bread samples using standard procedures as described by [1113]:

\subsubsection{Test for Alkaloid}

Two (2.0) $\mathrm{g}$ of each extract were dissolved in $2 \mathrm{~mL}$ of $10 \%$ hydrochloric acid and then filtered. A portion of the filtrates was treated with $1 \mathrm{~mL}$ of Mayer's reagent (potassium mercuric iodine solution). The formation of a yellow precipitate indicated the presence of alkaloid. Accordingly, the other portions of the filtrates were treated with Dragendrof's reagent (solution of potassium, bismuth, 
iodine). The formation of a red precipitate in each case indicated the presence of alkaloid.

\subsubsection{Test for Flavonoids}

Accurate weights $(0.5 \mathrm{~g})$ of each sample were dissolved in $2 \mathrm{~mL}$ distilled water in test tubes. The formation of orangeyellow colour on addition of small pieces of magnesium ribbon into each of the resulting solution indicated the presence of flavonoids.

\subsubsection{Test for Saponins}

Frothing Test: Accurate weights $(0.5 \mathrm{~g})$ of each sample were shaken vigorously with $2 \mathrm{~mL}$ distilled water in test tubes and observed for frothing. The persistence of frothing on warming after 15 minutes indicated the presence of saponins.

Test for Sugar Portions of Saponins: Accurate weights $(0.5$ g) of each sample were shaken with distilled water in test tubes. Two (2) mL each of Fehling's solutions A and B were added to the mixture and boiled. Brick red precipitates indicated positive results.

\subsubsection{Test for Tannins}

Accurate weights $(2.0 \mathrm{~g})$ of finely ground of each sample were shaken with distilled water and filtered. Two (2) $\mathrm{mL}$ of dilute ferric chloride solution were added to the filtrates. Blue black precipitates indicated the presence of tannins.

\subsubsection{Test for Glycosides}

Accurate weights $(0.5 \mathrm{~g})$ of finely ground of each sample were dissolved in $2 \mathrm{~mL}$ of chloroform in test tubes. Two (2) $\mathrm{mL}$ of concentrated sulphuric acid were carefully added along the side of the test tubes. Reddish brown rings observed at the interphase of the two liquids indicated the presence of steroidal ring which is the characteristic of cardiac glycosides.

\subsubsection{Test for Steroids}

Accurate weights $(0.5 \mathrm{~g})$ of finely ground of each bread sample were dissolved in $10 \mathrm{~mL}$ of chloroform and equal volumes of concentrated sulphuric acid were carefully added along the sides of the test tubes. Reddish upper layer and yellowish sulphuric acid lower layer with green fluorescence indicated the presence of steroids.

\subsection{Quantitative Phytochemical Analysis}

The following quantitative determinations for phytochemical analysis on the samples were carried using standard procedures as described by [14]:

\subsubsection{Determination of Saponins}

Accurate weights $(20 \mathrm{~g})$ of each of the finely ground bread sample were dispersed in $200 \mathrm{~mL}$ of $20 \%$ ethanol. The suspension was heated over a hot water bath for 4 hours with continuous stirring at about $55^{\circ} \mathrm{C}$. The mixture was filtered and the residue re-extracted with another $200 \mathrm{~mL}$ of $20 \%$ ethanol. The combined extracts were reduced to $40 \mathrm{~mL}$ over water bath at about $90^{\circ} \mathrm{C}$. The concentrate was transferred into a $250 \mathrm{~mL}$ separator funnel and $20 \mathrm{~mL}$ diethyl ether were added and shaken vigorously. The aqueous layer was recovered while the ether layer was discarded and the process repeated? Sixty (60) $\mathrm{mL}$ n-butanol extracts were washed twice with $10 \mathrm{~mL}$ of $5 \%$ aqueous sodium chloride. The remaining solution was heated in a water bath. After evaporation, the samples were dried in the oven to constant weights.

\subsubsection{Determination of Cardiac Glycosides}

Accurate weight (1 g) of finely ground of each bread sample was taken in a $100 \mathrm{~mL}$ volumetric flask, $60 \mathrm{~mL}$ distilled water and $8 \mathrm{~mL} 12.5 \%$ lead acetate were added, mixed thoroughly and filtered. Quantitatively, $50 \mathrm{~mL}$ of the filtrate were transferred into another $100 \mathrm{~mL}$ flask and $8 \mathrm{~mL} 47 \% \mathrm{Na}_{2} \mathrm{HPO}_{4}$ were added to precipitate excess $\mathrm{Pb}^{2+}$ ion. These were mixed and made up to $100 \mathrm{~mL}$ with distilled water. The mixture was filtered twice through same filter paper to remove excess lead phosphate. Ten (10) $\mathrm{mL}$ of the purified filtrate were transferred into a clean Erlyn-Meyer flask and treated with $10 \mathrm{~mL}$ Bajet reagent. A blank was prepared using $20 \mathrm{~mL}$ distilled water and $10 \mathrm{~mL}$ of Bajet reagent in a test tube. This was allowed to stand for 1 hour for complete colour development and the colour intensity measured at $495 \mathrm{~nm}$ using a photospectrometer.

\subsubsection{Determination of Alkaloids}

Quantitatively, $2.0 \mathrm{~g}$ of each of the finely ground sample were taken a $50 \mathrm{~mL}$ beaker and $40 \mathrm{~mL} 10 \%$ acetic acid in ethanol were added and covered with aluminium foil and allowed to stand for about 4 hours, filtered and the extract concentrated in water bath to one-quarter of the original volume. Quantitatively, 15 drops of concentrated ammonium hydroxide were added drop wise to the extract until the precipitation was complete. The whole solution was allowed to settle and the precipitate collected and washed with ammonium hydroxide and then filtered (the initial weight of the filter paper was measured and noted before the filtration). The residue is the alkaloid, which was dried and weighed. The weight of the alkaloid was taken as: Final weight of filter paper + dried residue-initial weight of filter paper before filtration.

\subsubsection{Determination of Flavonoids}

Five (5) $g$ of each of the finely ground sample were extracted repeatedly with $50 \mathrm{~mL}$ of $80 \%$ aqueous methanol in a volumetric flask at room temperature and then filtered. The filtrate was transferred into a crucible (whose initial weight was measured and noted) and evaporated into dryness over a water bath and weighed to a constant weight to determine the flavonoid content.

\subsubsection{Determination of Steroid}

One (1) $g$ of each of the finely ground sample was taken and macerated with $20 \mathrm{~mL}$ of ethanol. The mixture was filtered and $2 \mathrm{~mL}$ of the filtrate were taken in a test tube and $2 \mathrm{~mL}$ of colour reagent added and allowed to stand for 30 minutes and the absorbance measured at $550 \mathrm{~nm}$. 


\subsubsection{Determination of Soluble Carbohydrate}

One (1) $g$ of each of the finely ground sample was taken and macerated with $50 \mathrm{~mL}$ distilled water. The mixture was filtered and $1 \mathrm{~mL}$ of the filtrate was taken in a test tube and 2 $\mathrm{mL}$ saturated picric acid added and the absorbance measured at $530 \mathrm{~nm}$.

\subsection{Antinutrient Analysis}

\subsubsection{Determination of Oxalate}

Oxalate in the samples was determined by using the method described by [15]. One (1) g of each of the finely ground sample was taken in a $250 \mathrm{~mL}$ volumetric flask, 190 $\mathrm{mL}$ distilled water and $10 \mathrm{~mL}$ of $6 \mathrm{M} \mathrm{HCl}$ were added. The mixture was heated in a water bath at $90^{\circ} \mathrm{C}$ for 4 hours and the digested sample was centrifuged at 2,000 rpm for 5 minutes. The supernatant was then diluted to $250 \mathrm{~mL}$. Three $50 \mathrm{~mL}$ aliquots of the supernatant were evaporated to $25 \mathrm{~mL}$ and the brown precipitate was filtered and washed. The combined solution was then titrated with concentrated ammonia solution in drops until the pink colour of methyl orange changed to yellow. The solution was then heated in a water bath at $90^{\circ} \mathrm{C}$ and the oxalate was precipitated with $5 \%$ $\mathrm{CaCl}_{2}$ solution and allowed to stand overnight and then centrifuged. The precipitate was washed with hot $25 \% \mathrm{H}_{2} \mathrm{SO}_{4}$ and diluted to $125 \mathrm{~mL}$ with distilled water and titrated against $0.05 \mathrm{M} \mathrm{KMnO}_{4}$. The amount of oxalate present was calculated as shown in (3).

$$
1 \mathrm{~mL} 0.05 \mathrm{M} \mathrm{KMnO}_{4}=2.2 \mathrm{mg} \text { Oxalate }
$$

\subsubsection{Determination of Phytate}

Phytic acid in the samples was determined from the procedure described by [16]. Quantitatively, $2.0 \mathrm{~g}$ of each of the finely ground sample were taken in a $250 \mathrm{~mL}$ conical flask and $100 \mathrm{~mL} 2 \%$ concentrated $\mathrm{HCl}$ added and allowed to stand for 3 hours and then filtered. Fifty (50) $\mathrm{mL}$ of the filtrate were taken in another flask and $10 \mathrm{~mL}$ distilled water added to give proper acidity. Ten (10) $\mathrm{mL}$ of $0.3 \%$ ammonium thiocyanate solution were added as indicator and titrated with standard $\mathrm{FeCl}_{2}$ solution containing $0.00195 \mathrm{~g}$ Iron/mL to a yellow end point which persisted for 5 minutes. The percentage phytic acid was calculated as shown in (4).

$$
\% \text { Phytic Acid }=y \times 1.19 \times 100
$$

where: $y=$ Titre value $\times 0.00195 \mathrm{~g}$.

\subsubsection{Determination of Hydrocyanic Acid}

Hydrocyanic acid was determined in the samples using the alkaline picrate method described by [17]. Five (5) $\mathrm{g}$ of powdered sample were taken in a $250 \mathrm{~mL}$ conical flask, 50 $\mathrm{mL}$ distilled water added and allowed to stay overnight and then filtered [18].

Preparation of Cyanide Standard Curve: Different concentrations of KCN solution containing 0.1 to $1.0 \mathrm{mg} / \mathrm{mL}$ cyanide were prepared. To $1 \mathrm{~mL}$ of the sample filtrate and standard cyanide solution in test tubes, $4 \mathrm{~mL}$ of alkaline picrate solution $\left(1.0 \mathrm{~g}\right.$ of picrate and $5.0 \mathrm{~g}$ of $\mathrm{Na}_{2} \mathrm{CO}_{3}$ in 200
$\mathrm{mL}$ distilled water) were added and incubated in water bath for 15 minutes. After colour development, the absorbance was read at $490 \mathrm{~nm}$ against blank containing only $1 \mathrm{~mL}$ distilled water and $4 \mathrm{~mL}$ alkaline picrate solution. The cyanide content was extrapolated from the cyanide standard curve. The cyanide contents were calculated as presented in (5).

$$
\text { Cyanide }\left(\frac{m g}{100 g}\right)=\frac{C}{\text { Weight of sample } \times 10}
$$

Where $C=$ Concentration $(\mathrm{mg})$ of cyanide content read off from the graph.

\subsubsection{Determination of Tannins}

The tannins content in the samples was determined from the method described by [19]. One (1) g of the test sample was taken in a conical flask and $10 \mathrm{~mL}$ of distilled water added. The mixture was shaken at 5 minutes interval for 30 minutes and filtered. Accurate volume of $2.5 \mathrm{~mL}$ of the supernatant was taken in a test tube and $2.5 \mathrm{~mL}$ standard tannic acid solution added and transferred into a $50 \mathrm{~mL}$ flask and $1 \mathrm{~mL}$ Folin-Denis reagent was added, followed by 2.5 $\mathrm{mL}$ saturated $\mathrm{Na}_{2} \mathrm{CO}_{3}$ solution. The absorbance was read at $720 \mathrm{~nm}$ after 90 minutes of incubation at room temperature. The percentages of tannins were determined as presented in (6).

$$
\text { Tannins (\%) }=A \times \frac{C}{A s} \times \frac{100}{W} \times \frac{V f}{V a}
$$

where: $A=$ Absorbance of test sample, $A s=$ Absorbance of standard solution, $C=$ Concentration of standard solution, $W$ $=$ Weight of sample used, $V f=$ Total volume of extract, and $V a=$ Volume of extract analysed.

\subsection{Proximate Analysis}

\subsubsection{Determination of Moisture Content}

The method described by [20] AOAC (1980) was adopted for the determination of moisture content in the samples. A clean crucible was dried to a constant weight in an oven at $110^{\circ} \mathrm{C}$, cooled in a desiccator and weighed $\left(\mathrm{W}_{1}\right)$. Two (2) g of finely ground sample were accurately transferred into the previously weighed crucible and reweighed $\left(\mathrm{W}_{2}\right)$. The crucible containing the sample was dried in an oven to a constant weight $\left(\mathrm{W}_{3}\right)$. The percentage of moisture content was calculated from (7).

$$
\% \text { Moisture Content }=\frac{\left[W_{2}-W_{3}\right]}{\left[W_{2}-W_{1}\right]} \times 100
$$

\subsubsection{Determination of Ash Content}

The method described by [20] was adopted for the determination of ash content in the samples. A porcelain crucible was dried in an oven at $100^{\circ} \mathrm{C}$ for 10 minutes, cooled in a desiccator and weighed $\left(\mathrm{W}_{1}\right)$. Quantitatively, $2 \mathrm{~g}$ of the finely ground sample were placed into the previously weighed porcelain crucible and reweighed $\left(\mathrm{W}_{2}\right)$, it was first ignited and then transferred into a furnace which was set at $550^{\circ} \mathrm{C}$. The sample was left in the furnace for eight hours to 
ensure proper ashing. The crucible containing the ash was then removed cooled in a desiccator and weighed $\left(\mathrm{W}_{3}\right)$. The percentage ash content was calculated from (8).

$$
\% \text { Ash Content }=\frac{\left[W_{2}-W_{1}\right]}{\left[W_{2}-W_{1}\right]} \times 100
$$

\subsubsection{Determination of Crude Lipid}

Crude lipid content in the samples was determined by soxhlet extraction method described by [21]. A clean, dried $500 \mathrm{~mL}$ round bottom flask containing few anti-bumping granules was weighed $\left(\mathrm{W}_{1}\right)$ and $300 \mathrm{~mL}$ of petroleum ether added. The extractor thimble weighing $20 \mathrm{~g}$ was fixed into the soxhlet unit. The round bottom flask and a condenser were connected to the soxhlet extractor and cold water circulation was also connected. The heating mantle was switched on and the heating rate was adjusted until the solvent was refluxing at a steady rate. Extraction was carried out for 6 hours. The solvent was recovered and the oil dried in an oven at $70^{\circ} \mathrm{C}$ for 1 hour. The round bottom flask and oil was then weighed $\left(\mathrm{W}_{2}\right)$. The lipid content was calculated using (9).

$$
\% \text { Crude Lipid Content }=\frac{\left[W_{2}-W_{1}\right]}{[\text { Weight of Sample }]} \times 100(9)
$$

\subsubsection{Determination of Crude Fibre}

The method described by [21] AOAC (1999) was adopted for the determination of crude fire in the samples. Quantitatively, $2 \mathrm{~g}$ of the finely ground sample were taken in a round bottom flask, $100 \mathrm{~mL} 0.25 \mathrm{M}$ sulphuric acid solution were added and the mixture was boiled under reflux for 30 minutes. The hot solution was quickly filtered under suction. The insoluble matter was washed several times with hot water until it was acid free and then transferred into the flask and $100 \mathrm{~mL}$ of hot $0.31 \mathrm{M}$ sodium hydroxide solution were added and the mixture allowed to boil under reflux for 30 minutes and filtered under suction. The residue was washed with boiling water until it was base free and then dried to a constant weight in an oven at $100^{\circ} \mathrm{C}$. It was then cooled in a desiccator and weighed $\left(C_{1}\right)$. The weighed sample $\left(C_{1}\right)$ was then incinerated in a muffle furnace at $550^{\circ} \mathrm{C}$ for 2 hours, cooled in a desiccator and reweighed $\left(\mathrm{C}_{2}\right)$. The $\%$ crude fibre was calculated from (10).

$$
\% \text { Crude Fibre }=\frac{\left[C_{1}-C_{2}\right]}{[\text { Weight of Sample }} \times 100
$$

where: $C_{1} C_{2}=$ Loss in weight on incineration

\subsubsection{Determination of Crude Protein}

Determination of crude protein in the samples was done by using the Kjeldahl method described by [22]. The various reactions taking place are shown in (11) to (14).

$$
\% \text { Carbohydrate }=100-[\% \text { Moisture }+\% \text { Ash }+\% \text { Fat }+\% \text { Protein }+\% \text { Fibre }]
$$

\subsubsection{Determination of Calorific Value (Energy)}

Calorific value of each of the samples was obtained by multiplying the values of protein, lipid and carbohydrate by Atwater factors 4, 9 and $4 \mathrm{kcal}$, respectively and taking the

$$
\begin{gathered}
\mathrm{N}_{2}+4 \mathrm{H}_{2} \mathrm{SO}_{4} \rightarrow\left(\mathrm{NH}_{4}\right)_{2} \mathrm{SO}_{4} \\
\left(\mathrm{NH}_{4}\right)_{2} \mathrm{SO}_{4}+2 \mathrm{NaOH} \rightarrow \mathrm{Na}_{2} \mathrm{SO}_{4}+2 \mathrm{H}_{2} \mathrm{O}+2 \mathrm{NH}_{3} \\
2 \mathrm{NH}_{3}+2 \mathrm{H}_{3} \mathrm{BO}_{3} \rightarrow 2 \mathrm{NH}_{4} \mathrm{H}_{2} \mathrm{BO}_{3}
\end{gathered}
$$

Ammonium borate

$$
\mathrm{NH}_{4} \mathrm{H}_{2} \mathrm{BO}_{3} \rightarrow \mathrm{NH}_{4} \mathrm{Cl}+\mathrm{H}_{3} \mathrm{BO}_{3}
$$

One (1) $g$ of each of the samples was accurately taken in a standard $250 \mathrm{~mL}$ kjeldahl flask containing $1.5 \mathrm{~g} \mathrm{CuSO}_{4}$ and $1.5 \mathrm{~g} \mathrm{Na}_{2} \mathrm{SO}_{4}$ as catalysts and $5 \mathrm{~mL}$ concentrated $\mathrm{H}_{2} \mathrm{SO}_{4}$. The Kjeldahl flask (digestion) was heated gently on a heating mantle to prevent frothing until a clear bluish solution was obtained. The digestion solution was allowed to cool and then transferred quantitatively to a $100 \mathrm{~mL}$ standard flask and made up to the mark with distilled water. A $20 \mathrm{~mL}$ portion of the digest were taken in a semi micro kjeldahl distillation apparatus and treated with equal volume of $40 \% \mathrm{NaOH}$ solution. The ammonia evolved was steam distilled into a $100 \mathrm{~mL}$ conical flask containing $10 \mathrm{~mL}$ of saturated boric acid to which 2 drops of methyl red and methylene blue known as Tashirus indicator (double indicator) were added. The tip of the condenser was immersed into the boric acid double indicator solution and the distillation continued until about $2 / 3$ of the original volume was obtained. The tip of the condenser was rinsed with a few $\mathrm{mL}$ of distilled water in the distillate which was then titrated with $0.1 \mathrm{M} \mathrm{HCl}$ to a purple pink end point. The blank determination was carried out in a similar manner but the omission of the sample. The crude protein was obtained by multiplying the $\%$ Nitrogen content by a factor (6.25) as shown in (15).

$\%$ Crude Protein $=\%$ Nitrogen $\times$ Factor (i.e. 6.25$)$

The $\%$ Nitrogen was then calculated from (16).

$\%$ Nitrogen $=\frac{(\text { Sample Titre }- \text { Blank titre }) \times 0.1 \times 0.014}{\text { Weight of Sample }} \times \frac{20}{10} \times \frac{100}{1}(16)$

Most protein contain about $16 \%$ Nitrogen, so that $16 \mathrm{mg}$ $\mathrm{N}_{2}=100 \mathrm{mg}$ protein.

$$
\therefore 1 \mathrm{mg} N_{2}=\frac{100}{16}=6.25 \mathrm{mg} \text { of protein }
$$

The Nitrogen value was therefore multiplied by 6.25 to get the weight of protein.

\subsubsection{Determination of Total Carbohydrate}

The total carbohydrate in each sample was determined by differences obtained after subtracting the sum of the percentage moisture, ash, crude lipid, crude protein and crude fibre from 100 [23] as shown in (18). sum of the products as shown in (19).

$$
\text { Calorific Value }=[4 \times \% \text { Protein }+9 \times \% \text { lipid }+4 \times
$$$$
\text { Carbohydrate]Kcal }
$$ 


\subsection{Determination of Bromate}

Spectrophotometric measurements were made on a Jenway 6305 UV-Visible spectrophotometer. The absorbance was measured at $\lambda \max =485 \mathrm{~nm}$ for samples containing crystal violet and $452 \mathrm{~nm}$ for samples containing congo red.

Quantitatively, $2.5 \mathrm{~g}$ of each powdered sample were taken in a $250 \mathrm{~mL}$ beaker and $25 \mathrm{~mL}$ of water was added. The mixture was centrifuged and the liquid fraction diluted to 50 $\mathrm{mL}$ in a volumetric flask. Four (4) $\mathrm{mL}$ aliquots of each of the 4 bread samples were taken in 8 separate $25 \mathrm{~mL}$ calibrated flasks and five (5) $\mathrm{mL}$ of $5 \times 10^{-4} \mathrm{M}$ solution of congo red dye or crystal violet dye were added into each of the 8 flasks and followed by $10 \mathrm{~mL}$ of $2 \mathrm{M} \mathrm{HCl}$ solution. The contents of each flask were diluted to the $25 \mathrm{~mL}$ marks with distilled water and shaken gently prior to analysis. The concentrations of the samples were obtained from (20) and (21) for crystal violet and congo red, respectively.

$$
\begin{aligned}
& y=0.0047 x+0.2267 \\
& y=0.0011 x+0.5558
\end{aligned}
$$

where: $\mathrm{y}=$ Absorbance, and $\mathrm{x}=$ concentration of potassium bromate [24].

\subsection{Elemental Analysis}

\subsubsection{Determination of Mineral Elements}

Mineral elements in the bread samples were determined using atomic absorption spectrophotometry (AAS) after acid digestion of the samples [21]. Two (2) g of the finely ground samples were digested with concentrated nitric acid $\left(\mathrm{HNO}_{3}\right)$ and concentrated hydrochloric acid $(\mathrm{HCl})$ in the ratio 1:3. The mixtures were placed on a water bath for three hours at $80^{\circ} \mathrm{C}$. The resultant solutions were cooled and filtered into $100 \mathrm{~mL}$ standard flask each and made up to the mark with distilled water. The absorbance reading for the elements were recorded and the levels of the elements were determined by extrapolation from the calibration curves of the standards. The standards were prepared from individual $1000 \mathrm{ppm}$ stock solution of the respective metals initially prepared from their respective salts. Mineral elements levels were determined as shown in (22).

$$
\text { Mineral Element level }=\frac{\text { Absorbance of Sample } \times \text { Conc.of Standard } \times D F}{\text { Absorbance of Std } \times \text { Weight of Sample }}
$$

where: $\mathrm{DF}=$ Dilution factor, Conc. $=$ Concentration, and Std. $=$ Standard

\subsubsection{Determination of $\mathrm{Na}$ and $\mathrm{K}$ by Flame Emission Spectrophotometry}

The levels of sodium $(\mathrm{Na})$ and potassium $(\mathrm{K})$ in the samples were determined using flame emission spectrophotometer described in [21]. Aliquots of the digested samples were sucked into the flame and the emission intensity of sodium and potassium were recorded at $589 \mathrm{~nm}$ and $767 \mathrm{~nm}$, respectively. The levels of $\mathrm{Na}$ and $\mathrm{K}$ were deduced through extrapolation from the calibration curves earlier prepared from the standard solutions of the respective metals from (22) as shown above.

\subsection{Determination of Phosphorus}

The levels of phosphorus in the samples were determined by colorimetric method as described by [22]. In this method, $2 \mathrm{~g}$ of sample were digested with $0.5 \mathrm{M} \mathrm{HCl}$ and $1 \mathrm{~mL}$ of hydroquinone (the reducing agent) added. The mixture was agitated and allowed to stand for 30 minutes. The blue colour that developed was determined quantitatively at $660 \mathrm{~nm}$ using a UV spectrophotometer.

\subsection{Determination of Vitamins}

\subsubsection{Determination of Vitamin A}

The method described by [22] was used. Quantitatively, 20 $\mathrm{g}$ of antimony trichloride $\left(\mathrm{SbCl}_{3}\right)$ was dissolved in $100 \mathrm{~mL}$ of chloroform by warming slightly on a heating mantle, cooled in ice water until excess of reagent separated. The supernatant was used for colour development in the entire test. One (1) $\mathrm{g}$ of vitamin A was dissolved in $100 \mathrm{~mL}$ of chloroform. This solution contained $10 \mathrm{mg} / \mathrm{mL}$ of vitamin A.

Working Standard: Range of 1, 2, 3, 4 and $5 \mathrm{~mL}$ were prepared from the stock and making it up to $10 \mathrm{~mL}$ with chloroform in each case. Exactly $2 \mathrm{~mL}$ of the $\mathrm{SbCl}_{3}$ solution were added to these standards and allowed to stand for colour (blue) to develop. Their absorbances were determined at 620 nm using chloroform $\mathrm{SbCl}_{3}$ as blank.

One (1) $g$ of finely ground sample was taken in a beaker and $10 \mathrm{~mL}$ of chloroform added. The chloroform layer was taken in another test tube. This was tested with $\mathrm{SbCl}_{3}$ reagent to develop a blue colour. This was read at $620 \mathrm{~nm}$ against chloroform $/ \mathrm{SbCl}_{3}$. The levels of vitamin $\mathrm{A}$ in each of the sample were then calculated using (23).

$$
\text { Vitamin } A\left(\frac{m g}{L}\right)=\frac{\text { Absorbance of Sample } \times \text { Conc.of Standard } \times D F}{\text { Absorbance of Std. } \times \text { Weight of Sample }}
$$

where: $\mathrm{DF}=$ Dilution factor, Conc. $=$ Concentration, and Std. $=$ Standard

\subsubsection{Determination of Vitamin $C$ (Ascorbic Acid)}

The method described by [22] was used. Ascorbic acid reacts with 2, 4-dinitrophenylhydrazine to give dehydroascorbic acid. Ascorbic acid is oxidized to dehydroascorbic acid by cupric sulphate. The dehydroascorbic acid solution reacts with 2, 4dinitrophenylhydrazine to form 2, 4-dinitrophenylhydrazone. The hydrazine in the presence of strong sulphuric acid solution develops red colour which can be measured spectrophotometrically. Thiourea was added to the 2, 4dinitrophenylhydrazine reagent to prevent the oxidation of 
the 2, 4-dinitrophenylhydrazine reagent by interfering substances.

Preparation of $50 \mathrm{mg} / 100 \mathrm{~mL}$ ascorbic acid stock standards: An exact amount of $50 \mathrm{mg}$ of ascorbic acid was dissolved in $6 \mathrm{~g} / 100 \mathrm{~mL}$ trichloroacetic acid (TCA) and diluted to a final volume of $100 \mathrm{~mL}$.

Preparation of $5 \mathrm{mg} / 100 \mathrm{~mL}$ Intermediate Ascorbic Acid Standard: An aliquot of $10 \mathrm{~mL}$ of the stock standard was taken in a $100 \mathrm{~mL}$ standard volumetric flask and diluted to a final volume of $100 \mathrm{~mL}$ with $6 \mathrm{~g} / 100 \mathrm{~mL}$ TCA. In a series of $25 \mathrm{~mL}$ volumetric flasks, the following amount of the intermediate standards: $0.5,2,4,6,10,15$ and $20 \mathrm{~mL}$ were prepared. These were diluted to a final volume of $25 \mathrm{~mL}$ with $6 \mathrm{~g} / 100 \mathrm{~mL}$ TCA to yield working standards with concentrations: $0.10,0.40,0.80,1.20,2.00,3.00$ and 4 $\mathrm{mg} / 100 \mathrm{~mL}$.
One (1) $\mathrm{mL}$ of the clear solution was taken in a test-tube. The standards were taken in another test tubes and $1 \mathrm{~mL}$ of the $6 \mathrm{~g} / 100 \mathrm{~mL}$ TCA was taken in a different test-tube as a blank. One (1) $\mathrm{mL}$ of DTCS reagent (3 $\mathrm{g}$ of 2, 4dinitrophenylhydrazine, $0.4 \mathrm{~g}$ of thiourea, and $0.05 \mathrm{~g}$ of copper sulphate dissolved in $100 \mathrm{~mL}$ of $9 \mathrm{~N}$ sulphuric acid) was added to all the test tubes, which were caped, mixed and incubated in a water bath at $37^{\circ} \mathrm{C}$ for 3 hours. The test tubes were removed from the water bath and chilled for 10 minutes in an ice bath while mixing slowly and $2 \mathrm{~mL}$ of cold $12 \mathrm{M}$ $\mathrm{H}_{2} \mathrm{SO}_{4}$ were added to each of the test tubes. The spectrophotometer was adjusted with the blank to read zero absorbance at $520 \mathrm{~nm}$ and then absorbances of standard and test solution were recorded. The result in $\mathrm{mg} / \mathrm{mL}$ of vitamin $\mathrm{C}$ was extrapolated from the standard plot and calculated from (24).

$$
\text { Vitamin } C\left(\frac{m g}{L}\right)=\frac{\text { Absorbance of Sample } \times \text { Conc.of Standard } \times D F}{\text { Absorbance of Std. } \times \text { Weight of Sample }}
$$

where: $\mathrm{DF}=$ Dilution factor, Conc. $=$ Concentration, and Std. $=$ Standard

\subsubsection{Determination of Vitamin B2 (Riboflavin)}

Riboflavin was determined using the method described by [25]. Standard stock solution of riboflavin was prepared by dissolving $100 \mathrm{mg}$ of riboflavin in $100 \mathrm{~mL}$ of $0.1 \mathrm{~N} \mathrm{NaOH}$ which gives $1000 \mathrm{ppm}$. Ten (10) $\mathrm{mL}$ of this stock solution were taken and diluted to $100 \mathrm{~mL}$ with $0.1 \mathrm{~N} \mathrm{NaOH}$, to make 100 ppm solution.

The working standard was prepared by pipetting $1.5 \mathrm{~mL}$ stock solution into a $10 \mathrm{~mL}$ volumetric flask and made up to the mark with $0.1 \mathrm{~N} \mathrm{NaOH}$, to give $15 \mathrm{ppm}$.

Accordingly, 0.5, 1.0, 1.5, 2.0, 2.5 and $3.0 \mathrm{~mL}$ of $100 \mathrm{ppm}$ solution were diluted to $10 \mathrm{~mL}$ with $0.1 \mathrm{~N} \mathrm{NaOH}$, to produce $5,10,15,20,25$ and 30 ppm, respectively.

One (1) $\mathrm{g}$ of the finely ground sample was dissolved in 10 $\mathrm{mL} 0.1 \mathrm{~N} \mathrm{NaOH}$ and the resulted solution was filtered into a $25 \mathrm{~mL}$ volumetric flask. The absorbance was recorded at 445 $\mathrm{nm}$ and the vitamin B2 (Riboflavin) concentration was determined by extrapolation from the calibration curve of the standards.

\subsection{Data Analyses}

The analyses were performed in triplicates and data collected were analysed using SPSS. Differences between means were evaluated using ANOVA. Statistical significant difference was stated at $\mathrm{p}<0.05$.

\section{Results and Discussion}

The results obtained from this study are presented in Tables 1 to 8 . The trace metals levels are presented in Table 1. Table 2 showed the potassium bromate composition of the bread samples. Table 3 showed the qualitative phytochemical composition of the bread samples, while Table 4 showed the quantitative phytochemical composition. Table 5 showed the proximate composition of the bread samples. Table 6 showed the anti-nutrients composition of the bread samples. Table 7 showed the levels of essential minerals of the bread samples and Table 8 showed the vitamin levels of the bread samples.

Table 1. Trace metal levels ( $\mathrm{mg} / 100 \mathrm{~g}$ ) of the bread samples.

\begin{tabular}{lllll}
\hline \multirow{2}{*}{ Trace Metals } & Bread Samples & & \\
\cline { 2 - 5 } & A & B & C & D \\
\hline $\mathrm{Cu}$ & $\mathrm{BDL}$ & $<0.002$ & BDL & $<0.009$ \\
$\mathrm{Fe}$ & $<0.002$ & $<0.001$ & $\mathrm{BDL}$ & $<0.002$ \\
$\mathrm{~Pb}$ & $\mathrm{BDL}$ & $\mathrm{BDL}$ & $\mathrm{BDL}$ & $\mathrm{BDL}$ \\
$\mathrm{Sn}$ & $<0.001$ & $\mathrm{BDL}$ & $\mathrm{BDL}$ & $\mathrm{BDL}$ \\
\hline
\end{tabular}

$\mathrm{BDL}=$ below detectable level of the AAS.

Table 2. Potassium bromate composition $(\mathrm{mg} / \mathrm{kg})$ of the bread samples.

\begin{tabular}{lllll}
\hline \multirow{2}{*}{ Bromate } & Bread Samples & & \\
\cline { 2 - 4 } & A & B & C & $52.19^{\mathrm{c}} \pm 0.00$ \\
\hline Congo Red Oxidation & $6.66^{\mathrm{a}} \pm 0.00$ & $15.59^{\mathrm{b}} \pm 0.00$ & $\mathbf{D}$ & $20.70^{\mathrm{b}} \pm 0.00$ \\
Crystal Violet Oxidation & $5.09^{\mathrm{a}} \pm 0.00$ & $17.40^{\mathrm{b}} \pm 0.00$ & $56.36^{\mathrm{c}} \pm 0.00$ & $24.70^{\mathrm{b}} \pm 0.00$ \\
\hline
\end{tabular}

Above values are means \pm standard deviations of triplicate analysis. Within row, means with different letters are significantly different ( $\mathrm{p}<0.05)$. 
Table 3. Qualitative phytochemical composition of the bread samples.

\begin{tabular}{|c|c|c|c|c|}
\hline \multirow{2}{*}{ Phytochemicals } & \multicolumn{4}{|c|}{ Bread Samples } \\
\hline & $\mathbf{A}$ & B & $\mathbf{C}$ & D \\
\hline Saponin & ++ & ++ & ++ & ++ \\
\hline Alkaloid & +++ & +++ & +++ & +++ \\
\hline Glycoside & +++ & +++ & +++ & +++ \\
\hline Flavonoid & - & - & - & ++ \\
\hline Steroid & ++ & ++ & ++ & ++ \\
\hline
\end{tabular}

$+++=$ Present in high amount: $+=$ present in trace amount.

$++=$ Moderately present: $-=$ absent.

Table 4. Quantitative phytochemical composition $(\mathrm{mg} / 100 \mathrm{~g})$ of the bread samples.

\begin{tabular}{|c|c|c|c|c|}
\hline \multirow{2}{*}{ Phytochemicals } & \multicolumn{4}{|c|}{ Bread Samples } \\
\hline & $\mathbf{A}$ & B & $\mathrm{C}$ & D \\
\hline Saponins & $0.42^{\mathrm{a}} \pm 0.00$ & $0.41^{\mathrm{a}} \pm 0.00$ & $0.42^{\mathrm{a}} \pm 0.00$ & $0.47^{\mathrm{a}} \pm 0.00$ \\
\hline Alkaloids & $3.76^{\mathrm{a}} \pm 0.00$ & $3.12^{\mathrm{a}} \pm 0.00$ & $3.26^{\mathrm{a}} \pm 0.00$ & $1.06^{\mathrm{a}} \pm 0.00$ \\
\hline Glycosides & $0.08^{\mathrm{a}} \pm 0.00$ & $0.10^{\mathrm{a}} \pm 0.00$ & $1.87^{\mathrm{a}} \pm 0.00$ & $0.09^{\mathrm{a}} \pm 0.00$ \\
\hline Flavonoids & - & - & - & $2.76^{\mathrm{a}} \pm 0.00$ \\
\hline Steroids & $0.26^{\mathrm{a}} \pm 0.00$ & $0.39^{\mathrm{a}} \pm 0.00$ & $0.31^{\mathrm{a}} \pm 0.00$ & $0.19^{\mathrm{a}} \pm 0.00$ \\
\hline
\end{tabular}

Above values are means \pm standard deviations of triplicate analyses. Within row, means with different letters are significantly different ( $<<0.05$ ).

Table 5. Proximate composition (\%) of the bread samples.

\begin{tabular}{|c|c|c|c|c|}
\hline \multirow{2}{*}{ Proximate Composition } & \multicolumn{4}{|c|}{ Bread Samples } \\
\hline & $\mathbf{A}$ & B & C & D \\
\hline Moisture & $22.40^{\mathrm{a}} \pm 0.14$ & $29.42^{\mathrm{a}} \pm 0.05$ & $23.52^{\mathrm{a}} \pm 0.02$ & $31.51^{\mathrm{a}} \pm 0.00$ \\
\hline Ash & $0.18^{\mathrm{a}} \pm 0.00$ & $0.15^{\mathrm{a}} \pm 0.00$ & $0.92^{\mathrm{a}} \pm 0.00$ & $0.92^{\mathrm{a}} \pm 0.00$ \\
\hline Fibre & $0.03^{\mathrm{a}} \pm 0.00$ & $0.08^{\mathrm{a}} \pm 0.00$ & $0.03^{\mathrm{a}} \pm 0.00$ & $0.03^{\mathrm{a}} \pm 0.00$ \\
\hline Protein & $3.86^{\mathrm{a}} \pm 0.00$ & $2.27^{\mathrm{a}} \pm 0.00$ & $2.97^{\mathrm{a}} \pm 0.00$ & $3.32^{\mathrm{a}} \pm 0.00$ \\
\hline Lipid & $8.42^{\mathrm{a}} \pm 0.01$ & $11.31^{\mathrm{a}} \pm 0.01$ & $5.97^{\mathrm{a}} \pm 0.01$ & $5.00^{\mathrm{a}} \pm 0.00$ \\
\hline $\mathrm{CHO}$ & $65.04^{\mathrm{a}} \pm 0.01$ & $56.69^{\mathrm{a}} \pm 0.01$ & $73.38^{\mathrm{a}} \pm 0.00$ & $59.22^{\mathrm{a}} \pm 0.00$ \\
\hline Calorific Value (kcal) & $351.15^{\mathrm{a}} \pm 0.09$ & $337.57^{\mathrm{a}} \pm 0.00$ & $359.25^{\mathrm{a}} \pm 0.01$ & $280.10^{\mathrm{a}} \pm 0.00$ \\
\hline
\end{tabular}

Above values are means \pm standard deviations of triplicate analyses. Within row, means with with different letters are significantly different ( $\mathrm{p}<0.05$ ).

Table 6. Anti-nutrient composition $(\mathrm{mg} / 100 \mathrm{~g})$ of the bread samples $\left(\times 10^{-3}\right)$.

\begin{tabular}{|c|c|c|c|c|}
\hline \multirow{2}{*}{ Anti-nutrient } & \multicolumn{4}{|c|}{ Bread Samples } \\
\hline & $\mathbf{A}$ & B & $\mathbf{C}$ & D \\
\hline $\mathrm{HCN}$ & $0.74^{\mathrm{a}} \pm 0.0$ & $0.30^{\mathrm{a}} \pm 0.00$ & $1.68^{\mathrm{a}} \pm 0.00$ & $1.45^{\mathrm{a}} \pm 0.00$ \\
\hline Oxalate & $1.67^{\mathrm{a}} \pm 0.00$ & $0.40^{\mathrm{a}} \pm 0.00$ & $0.51^{\mathrm{a}} \pm 0.00$ & $0.63^{\mathrm{a}} \pm 0.00$ \\
\hline Phytate & $0.38^{\mathrm{a}} \pm 0.00$ & $0.39^{\mathrm{a}} \pm 0.00$ & $0.59^{\mathrm{a}} \pm 0.00$ & $0.53^{\mathrm{a}} \pm 0.00$ \\
\hline Tannins & $0.23^{\mathrm{a}} \pm 0.00$ & $0.21^{\mathrm{a}} \pm 0.00$ & $0.64^{\mathrm{a}} \pm 0.00$ & $0.92^{\mathrm{a}} \pm 0.00$ \\
\hline
\end{tabular}

Above values are means \pm standard deviations of triplicate analyses. Within row, means with with different letters are significantly different ( $<<0.05$ ).

Table 7. Essential mineral composition ( $\mathrm{mg} / 100 \mathrm{~g})$ of the bread samples.

\begin{tabular}{|c|c|c|c|c|}
\hline \multirow{2}{*}{ Mineral } & \multicolumn{4}{|c|}{ Bread Samples } \\
\hline & $\mathbf{A}$ & B & $\mathrm{C}$ & D \\
\hline Calcium & $1.18^{\mathrm{a}} \pm 0.00$ & $1.89^{\mathrm{a}} \pm 0.00$ & $1.75^{\mathrm{a}} \pm 0.00$ & $1.22^{\mathrm{a}} \pm 0.00$ \\
\hline Sodium & $0.01^{\mathrm{a}} \pm 0.00$ & $0.03^{\mathrm{a}} \pm 0.00$ & $0.06^{\mathrm{a}} \pm 0.00$ & $0.01^{\mathrm{a}} \pm 0.00$ \\
\hline Phosphorus & $0.01^{\mathrm{a}} \pm 0.00$ & $0.02^{\mathrm{a}} \pm 0.00$ & $0.08^{\mathrm{a}} \pm 0.00$ & $0.01^{\mathrm{a}} \pm 0.00$ \\
\hline
\end{tabular}

Above values are means \pm standard deviations of triplicate analyses. Within row, means with different letters are significantly different ( $\mathrm{p}<0.05)$.

Table 8. Vitamins composition ( $\mathrm{mg} / 100 \mathrm{~g})$ of the bread samples.

\begin{tabular}{|c|c|c|c|c|}
\hline \multirow{2}{*}{ Vitamins } & \multicolumn{4}{|c|}{ Bread Samples } \\
\hline & $\mathbf{A}$ & B & $\mathbf{C}$ & D \\
\hline $\mathrm{A}$ & $0.32^{\mathrm{a}} \pm 0.00$ & $0.56^{\mathrm{a}} \pm 0.00$ & $0.49^{\mathrm{a}} \pm 0.00$ & $0.34^{\mathrm{a}} \pm 0.00$ \\
\hline B2 & $0.20^{\mathrm{a}} \pm 0.00$ & $0.21^{\mathrm{a}} \pm 0.00$ & $0.41^{\mathrm{a}} \pm 0.00$ & $0.19^{\mathrm{a}} \pm 0.00$ \\
\hline $\mathrm{C}$ & $4.18^{\mathrm{a}} \pm 0.00$ & $3.82^{\mathrm{a}} \pm 0.00$ & $4.62^{\mathrm{a}} \pm 0.00$ & $2.85^{\mathrm{a}} \pm 0.00$ \\
\hline
\end{tabular}

Above values are means \pm standard deviations of triplicate analyses. Within row, means with different letters are significantly different $(\mathrm{p}<0.05)$. 
As seen in Table 1, copper was not detectable in samples from bakeries A, C, and D but was less than $0.002 \mathrm{mg} / 100 \mathrm{~g}$ in samples from bakery B which was within the NIS 75: 2004 requirement of $0.1 \mathrm{mg} / \mathrm{kg}$ maximum. Iron levels were $<$ $0.002,<0.001,<0.009$ and $<0.002 \mathrm{mg} / 100 \mathrm{~g}$ in the bread samples from bakeries $\mathrm{A}, \mathrm{B}, \mathrm{C}$ and $\mathrm{D}$, respectively. These values were within the NIS 75: 2004 requirement of 1.5 $\mathrm{mg} / \mathrm{kg}$ maximum. Lead was not detectable in all the bread samples. This shows compliance to NIS 75: 2004 requirements of $0.1 \mathrm{mg} / \mathrm{kg}$ maximum. As reported by [26] lead causes cancer, damage the brain and kidney and ultimately death. Tin was $<0.001 \mathrm{mg} / 100 \mathrm{~g}$ in samples from bakery A, but below detectable limit in the samples from bakeries B, C and D. The NIS 75: 2004 requirement of tin in bread is $50.0 \mathrm{mg} / \mathrm{kg}$ maximum.

As shown in Table 2, potassium bromate contents determined with congo red oxidation method ranged from $6.66 \pm 0.00$ to $52.19 \pm 0.00 \mathrm{mg} / \mathrm{kg}$ in all the bread samples, while the potassium bromate contents determined with crystal violet oxidation method ranged from $5.09 \pm 0.00$ to $58.36 \pm 0.01 \mathrm{mg} / \mathrm{kg}$ in the bread samples. The results indicated none compliance of the affected bakeries to the ban on the use of potassium bromate as bread improver by NAFDAC. NAFDAC had since banned the use of potassium bromate as bread improver in Nigeria due to the dangers associated with its consumption. The levels of potassium bromate in the bread samples were significantly different at $p=0.05$. The ANOVA result for the potassium bromate composition gives the F-calculated value of 120.327 and probability value of 0.000 . Since the probability value was less than 0.05 (level of significance), it implies that there was significant difference in the potassium bromate composition in the bread samples from the four bakeries. Since the test was significant, pair wise comparison tests were conducted to check which of the sample was significantly different from the other. The test was carried out using Least Significant Difference (LSD) method. The LSD result revealed that the mean potassium bromate content of samples from bakery A was significantly less than that of samples from bakeries B, C and D since the respective probability values of $0.018,0.000$ and 0.004 were all less than 0.05 (level of significance). The mean of samples from bakery B was significantly less than that of samples from bakery $C$. The mean difference between samples from bakeries B and D were not significant since the p-value of 0.087 was greater than 0.05 (level of significance). The mean of samples from bakery $\mathrm{C}$ was significantly higher than that of samples from bakery $\mathrm{D}$.

As shown in Table 3, saponins and steroids were present in moderate amount in all the samples. Flavonoids were present in moderate amount in samples from bakery $\mathrm{D}$, while they were absent in samples from bakeries A, B and C. Alkaloids and glycosides were present in high amount in all the samples. Quantitatively, as presented in Table 4, phytochemical composition of the bread samples ranged from $0.08 \pm 0.00$ $\mathrm{mg} / 100 \mathrm{~g}$ glycosides in samples from bakery A to $3.76 \pm 0.00$ $\mathrm{mg} / 100 \mathrm{~g}$ alkaloids also in samples from bakery A. There were no significant differences at $p=0.05$ between each of the phytochemical parameters of the bread samples from the four bakeries. The analysis of variance (ANOVA) result for the phytochemical composition gives F-calculated value of 0.620 and probability value of 0.612 . Since the probability value was greater than 0.05 (level of significance), it implies that there was no significant difference between the values of each of the phytochemical composition of the bread samples in all the four bakeries surveyed.

From Table 5, the proximate composition of the bread samples ranged from $0.03 \pm 0.00$ fibre in samples from bakeries A, C and D to $73.38 \pm 0.00 \% \mathrm{CHO}$ in samples from bakery $\mathrm{C}$, while the calorific values of the bread ranged from $280.11 \pm 0.00$ to $359 \pm 0.00 \mathrm{kcal}$ in samples from all the bakeries. The moisture contents in all the samples were within the NIS 75: 2004 requirement of 40\% maximum. There was no significant difference at $p=0.05$ between the values of the moisture contents in samples from the four bakeries. Ash contents in samples from bakeries A and B were within the NIS 75: 2004 requirement of $0.6 \%$ maximum while those of samples from bakeries $\mathrm{C}$ and $\mathrm{D}$ were above the permissible level. The values of the ash contents showed no significant difference at $\mathrm{p}=0.05$ in all the samples. The fibre contents were within the NIS 75: 2004 requirement of $0.5 \%$ maximum. The fiber levels showed no significant difference at $\mathrm{p}=0.05$ in all the samples. Fibre aids in speeding up the excretion of wastes and toxins from the body, thus preventing them from sitting in the intestine or bowel for too long which could lead to several diseases [27]. Protein levels were below the NIS 75: 2004 requirement of $10 \%$ minimum. The values showed no significant difference at $\mathrm{p}=0.05$ in all the samples. The lipid levels were above NIS 75: 2004 requirement of 2.0\% maximum. The values showed no significant difference at $\mathrm{p}=0.05$. CHO contents were equally above the NIS 75: 2004 requirement of 48\% maximum. The values showed no significant difference at $p$ $=0.05$. CHO serves as stored form of energy as glycogen in the liver and muscles [28]. The calorific values showed no significant difference at $\mathrm{p}=0.05$ in all the samples. The ANOVA result for the proximate composition gives the Fcalculated value of 0.013 and probability value of 0.998 , indicating that there was no significant difference in the proximate composition of the bread samples from the four bakeries since the probability value was greater than 0.05 (level of significance).

In Table 6 , the anti-nutrient composition ranged from $0.21 \pm 0.00 \mathrm{mg} / 100 \mathrm{~g}$ tannins in samples from bakery B to $1.68 \pm 0.00 \mathrm{mg} / 100 \mathrm{~g} \mathrm{HCN}$ in samples from bakery C. HCN contents showed no significant difference at $\mathrm{p}=0.05$ in all the samples. According to [29], cyanide ions inhibit several enzymes systems and depress growth through interference with certain essential amino acid and utilization of associated nutrients. A high level of hydrocyanic acid has been implicated in cerebral damage and lethargy in man [30, 31]. Oxalate contents showed no significant difference at $\mathrm{p}=0.05$ in all the samples. Oxalates are known for their ability to 
bind calcium present in food thereby, rendering calcium unavailable for normal physiological and biochemical roles such as maintenance of strong bones, teeth, cofactor in enzymatic reaction, nerve impulse transmission and as clotting factor in blood [32]. Phytate contents showed no significant difference at $\mathrm{p}=0.05$ in all the samples. Phytates are associated with nutritional diseases such as rickets and osteomalacia in children and adults [33]. Tannins contents showed no significant difference at $p=0.05$ in all. Tannins are water soluble phenolic compounds that chelate Fe and $\mathrm{Zn}$ and limits absorption of these nutrients [34]. The ANOVA result for the anti-nutrient composition gives the F-calculated value of 1.180 and probability value of 0.358 . Since the probability value was greater than 0.05 (level of significance), it implies that there was no significant difference in the anti-nutrient composition of the bread samples from all the bakeries.

As presented in Table 7, essential mineral composition ranged from $0.01 \pm 0.00 \mathrm{mg} / 100 \mathrm{~g}$ phosphorus and sodium in samples from bakeries A and D to $1.89 \pm 0.00 \mathrm{mg} / 100 \mathrm{~g}$ calcium in samples from bakery B. There were no significant differences at $p=0.05$ between the levels of each of the investigated essential minerals in the bread samples from the four bakeries. The ANOVA result for the essential mineral levels gives the F-calculated value of 0.080 and probability value of 0.970 . It implies that there was no significant differences in the essential mineral composition of the bread samples, since the probability value was greater than 0.05 (level of significance). Calcium is important for blood clotting, muscle contraction, essential for nerve impulse conduction and activates some enzymes which generate neurotransmitters. It plays important role in building strong bones and teeth [35]. Sodium plays important role in blood pressure regulation [36]. Phosphorus like calcium is required for growth, maintenance of bones, teeth and muscles [37].

The vitamins composition as presented in Table 8 ranged from $0.19 \pm 0.00 \mathrm{mg} / 100 \mathrm{~g}$ vitamin $\mathrm{B} 2$ in samples from bakery D to $4.62 \pm 0.00 \mathrm{mg} / 100 \mathrm{~g}$ vitamin $\mathrm{C}$ in samples from bakery C. As noted in most of the parameters investigated, there were no significant differences at $p=0.05$ between the levels of each of the investigated vitamins in the bread samples from the four bakeries. The ANOVA result for the vitamins composition gives the F-calculated value of 0.061 and probability value of 0.979 . Since the probability value was greater than 0.05 (level of significance), it could be said that there was no significant differences in the vitamins composition of the bread samples.

\section{Conclusion and Recommendations}

Based on the analyses and results, it was concluded that the bread samples analysed in this study contained low levels of some of the investigated trace metals, variable levels of potassium bromate and appreciable levels of phytochemicals, nutrients, essential minerals and vitamins. The protein contents were however below the minimum requirement of $10 \%$ as specified in the standard for bread. It was also concluded that the bread samples contained low levels of anti-nutrients.

The variable levels of potassium bromate in all the bread samples analysed, suggested none compliance by the sampled bakeries to the ban by NAFDAC on the use of bromate as bread improver. However, the anti-nutrients and trace metals levels were below the levels that could cause toxicity in humans.

It could therefore be said that bread produced by the sampled bakeries in Uyo, Akwa Ibom State, Nigeria were to some extend nutritive, except that the bread contained potassium bromate (banned chemicals that are hazardous to human health),

It is recommended that protein contents in bread should be improve as the protein levels in the bread from all the sampled bakeries were far below the minimum requirement of $10 \%$ as specified in the standard for bread. NAFDAC and relevant regulatory bodies should ensure full implementation of the ban on the use of potassium bromate as bread improver in bread baking.

The study had contributed effectively to knowledge in the area of Food Chemistry. Data generated from this study will serve as baseline reference to other researchers in the area.

\section{References}

[1] Uwah, E. I., Moses, E. A. and Okokon, K. R. (2015). Proximate, mineral and antinutrient composition of Justica schinipen and Amaranthus viridis consumed in Idu, Uruan, Akwa Ibom State, Nigeria. International Journal of Current Research in Chemistry and Pharmaceutical Sciences, 2 (10): 24-30.

[2] Pomeranz, Y. (1987). Bread around the World. In: Pomeranz, Y. (Ed.), Modern Cereal Science and Technology. VCH Publishers Inc., New York, NY, 333 p.

[3] Owens, G. (1997). China: handled with care. Cereals International, 14-16.

[4] Magomya, A. M., Yebpella, G. G., Udiba, U. U., Amos, H. S. and Latayo, M. S. (2013). Potassium bromate and heavy metal content of selected bread samples produced in Zaria, Nigeria. International Journal of Science and Technology, 2 (2): 232-234.

[5] Vadlamani, K. R. and Seib, G. (1999). Effect of zinc and aluminium ions in bread baking. Cereal Chemistry, 76 (1): 355-360.

[6] Ahmad, A. B. (2013). Potassium Bromate Levels in Bread Samples, a Case Study of Some Selected Areas in Kano Metropolis. MSc. Dissertation. Bayero University Kano, Nigeria. $56 \mathrm{p}$.

[7] Maxiya-Dixen, B., Akinyele, I. O., Oguntuna, E. B., okoe, N., Sanusi, S. and Harrris, R. A. (2004). Nigerian Food Consumption and Nutritional Survey 2001-2003. IITA Ibadon. 67 p.

[8] Demirozu, B. and Saldamli, I. (2002). Metallic contamination problem in a pasta production plant. Turkish Journal Engineering and Environmental Sciences, 26: 361-365.

[9] Klaus, L. and Robert, L. (1987). Mineral composition of U.S. and Canadian wheat and wheat blends. Journal Agriculture and Food Chemistry, 25 (4): 806-809. 
[10] Onianwa, P. G., Idown, J. and Ogabiela, E. E. (2001). Copper and zinc contents of Nigerian foods and estimates of the adults dietary intakes. Food Chemistry, 72: 89-95.

[11] Sofowora, L. A. (1993). Medicinal Plants and Traditional Medicine in Africa. Spectrum Books Limited, Ibadan, 71 p.

[12] Ayoola, G. A., Coker, H. A., Adesegun, S. A. Adepoju-Bello A. A., Obaweya, K., Ezennia, E. C. and Atangbayila, T. O. (2008). Phytochemical screening and antioxidant activities of some selected medicinal plants accessed for malaria therapy in south-western Nigeria. Tropical Journal of Pharmaceutical Research, 7: 1019-1024.

[13] Uwah, E. I. and Mkpa E. R. (2016). Chemical evaluation and nutritive value of cultivated and wild Gongronema latifolium obtained in Etinan, Akwa Ibom State. Journal of Environmental Science, Toxicology and Food Technology, 10 (8): 70-83.

[14] Harborne, J. B. (1973). Phytochemical Methods, Champman and Hall, London. $113 \mathrm{p}$.

[15] Sanches-Alonso, F. and Lachica, M. (1987). Seasonal trends in the elemental content of plum leaves. Communications in Soil Science and Plant Analysis, 18: 31-44.

[16] Lucas, G. M. and Markakas. G (1975). Phytic acid and other phosphorus compounds of bean (phaseolus vulgaris). Journal of Food Science and Technology, 23: 13-15.

[17] Onwuka, S. K. and Olopade, J. O. (2005). Some aspects of the clinical anatomy of the mandibular and maxillofacial regions of the west African dwarf goat in Nigeria. International Journal of Morphology, 23 (1): 33-36.

[18] Inuwa, H. M., Aina, V. O., Baba, G., Aimola, C. and Amao, T. (2011). Comparative determination of antinutritional factors in groundnut oil and palm oil. Advanced Journal of Food Science Technology, 3 (4): 275-279.

[19] Kadhakrishna, M. R. and Silvaprasad, J. (1980). Tannins content of sorghum varieties and their roles in iron bioavailability. Journal Agriculture and food chemistry, 28: 5557.

[20] AOAC (Association of Official Analytical Chemists) (1980). Official Method of Analysis. 13th Edition. Association of Official Analytical Chemists, Washington DC. 384 p.

[21] AOAC (Association of Official Analytical Chemists) (1999). Official Methods of Analysis. 16th Edition. Association of Official Analytical Chemists, Washington DC. 792 p.

[22] AOAC (Association of Official Analytical Chemists) (2010). Official Method of Analysis, 17th Edition. Association of Official Analytical Chemists. Washington DC. U.S.A.

[23] Muller, H. G. and Tobin, G. (1980). Nutrition and Food Processing. Croom Heim, London.

[24] Narmeen, S. A. and Media, A. H. (2009). Spectrophotometeric determination of bromate in bread by the oxidation of dyes. Journal of Kirkuk University-Scientific Studies, 4 (1): 32-33.
[25] Shah, H., Patel, S., Patel, B., Solanki, N. and Jivania, N. P. (2012). Development and validation of uv-visible spectrometric method for estimation of water soluble vitamin riboflavin. International Journal of Pharmaceutical Sciences and Research, 3 (9): 3462-3466.

[26] Chinma, C. E and Igyor, M. A. (2007). Micronutrients and anti-nutritional contents of selected tropical vegetables grown in southeast Nigeria. Nigerian Food Journal, 25 (1): 111-116.

[27] Hunt, S., Groff, I. L. and Holbrook, J. (1980). Nutrition, Principles and Chemical Practice. John Wiley and Sons, New York, $462 \mathrm{p}$.

[28] Hassan, L. G., Sani, N. A., Dangogo, S. M. and Ladan, M. J. (2007): Nutritional value of bottle gourd (Lageneria siceraria) seeds. Global Journal of Pure and Applied Science, 14 (3): 301-306.

[29] Soetan, K. O. and Oyewale, O. E. (2009). The need for adequate processing to reduce the antinutritional factors in plants used as human foods and animal feeds: a review. African Journal of Food Science, 3: 223-232.

[30] Ebun-Oluwa, P. O. and Alade, A. S. (2007). Nutritional potential of belandiern nettle spurge Jatropha cathatica seed. Pakistan Journal of Nutrition, 6: 345-348.

[31] Agbaire, P. O. and Emoyan, O. O. (2012). Nutritional and anti-nutritional levels of some local vegetables from Delta State, Nigeria. African Journal of Food Science Technology, 6: 8-11.

[32] Ladeji, O., Akin C. U. and Umaru, H. A. (2004). Level of Anti-nutritional factors in vegetables commonly eaten in Nigeria. African Journal of Natural Science, 7: 71-73.

[33] Uwah, E. I. and Moses, E. A. (2015). Phytochemical and trace metal analyses of selected local spices plant consumed in Uyo, Akwa Ibom State, Nigeria. International Journal of Advanced Research in Chemical Sciences, 2: 25-31.

[34] Akande, K. E., Doma, U. D., Agu, H. O. and Adamu, H. M. (2010). Major anti-nutrient found in plant protein sources: their effect on nutrition. Pakistan Journal of Nutrition, 8: 827832 .

[35] Adeyeye, E. I. and Fagbohun E. D. (2005). Proximate, mineral and phytate profiles of some selected spices found in Nigeria. Pakistan Journal of Science Industrial Research, 48 (1): 14-22.

[36] Devesh, T., Pandey, H., Saha, A N., Meenab, H. S. and Manchandab, A. (2012). Pharmacognostical and biochemical investigation of Ocimum kilimandscharicum plants available in western himalayan region. Asian Journal of Plant Science and Research, 2 (4): 446-451.

[37] Turan, M., Kordali, S., Zengin, H., Dursun, A. and Sezen, Y. (2003). Macro and micromineral content of some wild edible leaves consumed in eastern Anatolia. Plant Soil Science, 53: 129-137. 